\title{
RATIONALE OF THE STRATEGIC DEVELOPMENT OF THE ENERGY INDUSTRY OF UKRAINE WITH USE OF RE- SOURCE-SAVING TECHNOLOGIES
}

\author{
Kushnir N.B. \\ National University of Water and Environmental Engineering \\ (NUWEE), Candidate of Sciences (Economics), Professor, \\ Department of Enterprise Economics, Ukraine \\ Moshchych S.Z. \\ National University of Water and Environmental Engineering \\ (NUWEE), Ph.D., Senior Lecturer, \\ Institute of Postgraduate Education, Ukraine \\ Veretin L.S. \\ National University of Water and Environmental Engineering \\ (NUWEE), Ph.D., Senior Lecturer, Institute of Postgraduate \\ Education, Ukraine

\section{Okseniuk R.R.} \\ National University of Water and Environmental Engineering \\ (NUWEE), Assistant, Department of Development of Deposits \\ and Mining, Ukraine
}

\section{Summary}

Energy is an important factor that has a direct impact on industrial relations, social development of society, the state of the environment. The scarcity of energy resources requires assessing them as a factor of economic security and taking them into account when formulating national and entrepreneurial strategies. The concept of energy security as the availability of energy for industrial and domestic consumption has become widespread in scientific works. At the same time, the driving force of any process is a strategic vision that builds a system of goals and develops concrete measures aimed at overcoming problem areas in the trajectory of achieving effective solutions.

The modern post-industrial period needs a new stage of energy development ecologically regulated, during which the organizational and economic mechanism should be formed as a result of ecological regulation. This will ensure the transition to sustainable development, characterized by economic and social progress while reducing the man-made impact of energy on the environment, which meets the needs of the knowledge economy. 


\section{Introduction}

Nature has provided mankind with an inexhaustible supply of energy, and taming and transforming it into forms suitable for use have given human civilization over the past centuries an unprecedented advance in material production and, consequently, in the spiritual development of society. Improvements in technology and growth in production are helping to better meet people's needs, but this process is contributing to increasing environmental pollution. The economic consequences of numerous natural disasters and man-made disasters, global epidemics are growing to alarming proportions, which, in turn, slows down both the development of the world economy as a whole and the solution of demographic, energy and food problems.

The issues of environmental efficiency in general and energy in particular are being investigated by scientists O. O. Veklych, T.P. Galushkina, O.D. Gnatkovich, L.S. Grinov, P.M. Gritsyuk, V.S. Kravtsiv, L.I. Maksimov, L.G. Melnik, O. Yu. Popova, S.M. Rogach, V.V. Sabadash, P.M. Skripchuk, A.Ya. Sokhnich, Y. Yu. Tunic, M.A. Khvesik, E. V. Khlobistov, L. M. Cherchik, R. Costanza, H. Daly, J. Dixon, J. Farley, R. de Groot, N. Hanley, J. Krutilla, D. Pearce and others. In recent years, considerable work has been done in Ukraine to address both scientific, technical and organizational and economic problems of improving energy supply. In particular, the directions of increasing energy efficiency were explored in their works by A. Borisenko, S. Denisyuk, D. Deregan, M. Kovalko, E. Krykavsky, M. Ksenofontov, V. Kuratchenko and others.

The interaction of human society and nature in the process of development of energy sources was not optimal at all stages of development. The rapid increase in energy consumption creates the risk of rapid depletion of fuel and energy resources. In addition, the dynamics of global energy consumption in the last century sufficiently indicate its exponential growth, which is a potential threat of an increase in excess heat emissions that can disrupt the thermal balance of the planet and lead to catastrophic changes in its climate. Therefore, the development of national energy using the methods of environmental regulation will contribute to the sustainable development of the fuel and energy complex.

The purpose of the work is to develop theoretical and methodological approaches for the strategic development of national energy, tak- 
ing into account the requirements of the European Community and to provide scientifically sound recommendations for its improvement, taking into account environmental, economic and social aspects.

In order to achieve this goal, it is envisaged to fulfill such tasks, namely to identify the types of energy development by the intensity of impact on the environment; identify trends in national energy; analyze the conditions for achieving the strategic priorities of national economy development; to develop scientific and practical recommendations for the development of the national energy complex to the requirements of the European Energy Community.

\section{Current state of energy efficiency of Ukraine}

Energy development has a decisive influence on the state of the economy in the country and the standard of living of the population. The aim of the welfare state, which, according to the Constitution, is Ukraine, is to provide conditions for increasing the well-being of citizens. One of the most important components of well-being in civilized states is to provide citizens and companies with the necessary energy resources. The key to achieving this goal should be a reliable, economically sound and environmentally sound meeting the needs of the population and the economy in energy products.

Ukraine is one of the energy scarce countries in the supply of basic primary energy, which necessitates significant volumes of their imports. The issue of Ukraine's energy independence has been particularly aggravated with the onset of Russian hybrid aggression against our country. Aggressive economic activities, the constant blackmailing of Russian state-owned corporations, and the threat of disruption of energy supplies from Russia (natural gas, nuclear fuel, oil and petroleum products) have forced us to look fundamentally at the issue of energy independence.

A key challenge that needs urgent response is the unsatisfactory technical condition of Ukraine's energy sector, which continues to deteriorate as a result of the aging of fixed assets. Most of the generating assets and energy networks are worn out and inefficient. The vast majority of thermal power plant units has exceeded the physical wear and tear and requires major upgrading or replacement; most nuclear power plant units are nearing the design lifetime. The power balance of Ukraine's power grid is characterized by a lack of regulatory capacity, which causes irrational use of existing capacity and a 
high level of losses. Emissions of dust, sulfur oxides and nitrogen by thermal power plants of Ukraine are several times higher than the corresponding norms of developed countries. A large proportion of the backbone and distribution network facilities has fulfilled their resources and is in need of modernization.

Inefficient use of energy resources, heat loss in buildings that do not have thermal insulation and electricity in the grids, energy consumption is turning a huge loss for Ukraine and affects the level of national energy security, economic development, cost of production, ecology, as well as elementary, the cost of living for citizens. According to experts, only inefficient energy consumption for heating residential and public buildings in Ukraine generates losses of $\$ 3$ billion annually (or $3 \%$ of national GDP). Equally large losses are causing the country and the use of outdated and inefficient technologies in industry.

Today, with a high level of import dependency, Ukraine is the most energy-intensive country in Europe. Low efficiency of use of fuel and energy resources causes high level of GDP energy intensity in Ukraine. By international standards, Ukraine's economy is one of the most energy-intensive economies in the world due to its large share of energy-intensive sectors, outdated and inefficient technologies, extremely worn-out fixed assets, inefficient energy transformation and supply systems, and energy-efficient building stock.

Instead of providing the extensive development that Ukraine's economy has been moving through for decades, the energy sector needs to move to effectively ensure sustainable economic development. Maintenance of economy and social sphere of the country with the main types of energy sources (electric and thermal energy, motor and boiler-fuel types, as well as natural gas) and raw materials for the needs of the chemical and metallurgical industry (coking coal, oil and gas products), is entrusted to complex energy sources of Ukraine.

\section{Strategic directions of national energy development}

Diversification of energy sources, enhancement of Ukraine's transit potential and development of alternative energy all require a sound energy infrastructure development policy.

However, Ukraine's state energy policy is characterized by a mismatch of economic and political interests at different levels of government. In the face of political instability, the role and sensitivity to 
the threats to the fuel and energy complex as a guarantor of the country's economic security is increasing. Along with other components of economic security, energy security forms the basis of economic relations, creating the conditions for GDP production.

The forecast of socio-economic development of Ukraine (ensuring GDP growth of Ukraine twice by 2035) is based on the need for radical technological renewal of the national economy and social sphere, implementation of corresponding large-scale investment projects. In this case, the forecast of economic development proceeds from the need to maximize the use of internal potential in the realization of these ambitious goals, which forms the prospect of loading the metallurgical, construction, transport and energy sectors of the national economy.

The dynamics of the development of individual sectors of the national economy and the structure of GDP formation are shown in Figs. 1 and fig. 2. The structure of output is shown in fig. 3 .

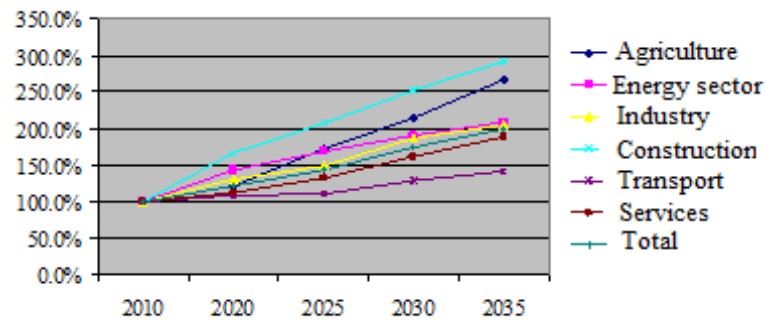

Fig. 1. Forecast of the dynamics of GDP formation by individual sectors of the national economy

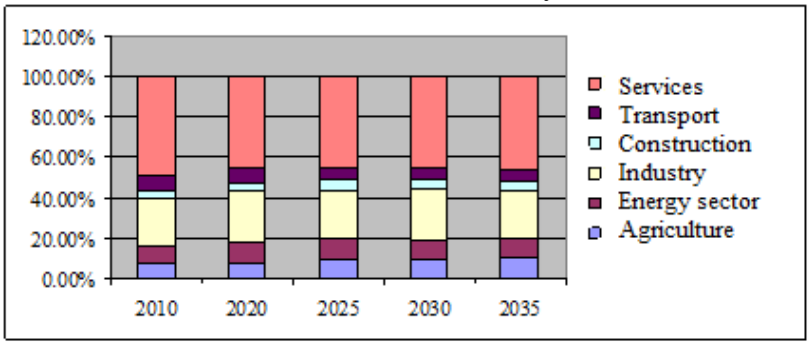

Fig. 2. Structure of GDP formation by sectors of national economy 


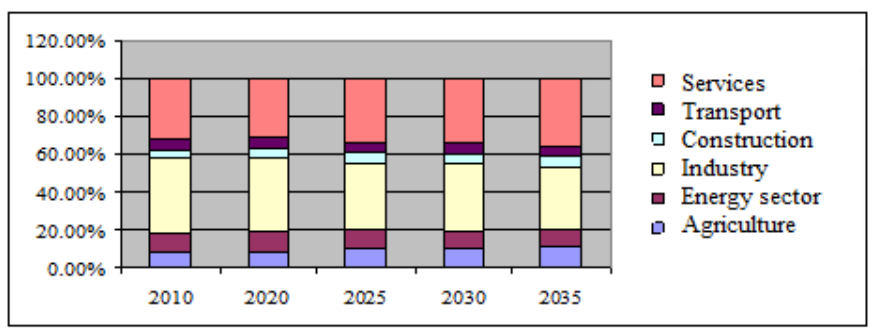

Fig. 3. Structure of output by sectors of the national economy

At the same time, Ukraine's international commitments and sustainable development goals impose on the national economy and the energy sector a number of restrictions on the need for innovative renewal of the energy sector, expansion of the use of renewable energy sources, reduction of energy intensity of the national economy, environmental impact, etc. The overall forecast energy balance of Ukraine for the period up to 2035, taking into account these limitations, is given in Table 2.

Table 2

Forecast balance of consumption of fuel and energy resources for the period up to 2035

\begin{tabular}{|c|c|c|c|c|}
\hline FER consumption, ppm & 2020 & 2025 & 2030 & 2035 \\
\hline Coal & 37.69 & 38.37 & 37.27 & 33.78 \\
\hline Natural gas & 37.33 & 33.57 & 33.20 & 34.17 \\
\hline Petroleum products & 13.97 & 14.86 & 15.74 & 16.48 \\
\hline Nuclear energy & 25.31 & 25.38 & 27.39 & 32.86 \\
\hline Biomass, biofuels and waste & 6.38 & 8.91 & 11.85 & 13.10 \\
\hline Solar energy & 0.37 & 0.56 & 0.70 & 0.84 \\
\hline Wind energy & 0.21 & 0.32 & 0.43 & 0.54 \\
\hline Hydraulic energy* & 0.93 & 1.02 & 1.21 & 1.25 \\
\hline Environmental energy & 0.78 & 1.42 & 1.86 & 2.40 \\
\hline Net exports & -1.03 & -1.29 & -2.15 & -2.58 \\
\hline Total, incl. & 121.92 & 123.12 & 127.49 & 132.84 \\
\hline not energy use & 4.72 & 4.96 & 5.16 & 5.31 \\
\hline energy use & 117.20 & 118.17 & 122.33 & 127.53 \\
\hline including RES & 8.66 & 12.23 & 16.05 & 18.12 \\
\hline $\begin{array}{l}\text { Share of RES in consumption of primary } \\
\text { resources, } \%\end{array}$ & 7.4 & 10.3 & 13.1 & 14.2 \\
\hline $\begin{array}{l}\text { GDP, billion USD United States (PCA } \\
\text { 2005) }\end{array}$ & 457 & 540 & 638 & 761 \\
\hline $\begin{array}{l}\text { Energy consumption, } \mathrm{kg} \mathrm{AD} \mathrm{/} \mathrm{thousand} \mathrm{US} \\
\text { dollars USA }\end{array}$ & 0.27 & 0.23 & 0.20 & 0.17 \\
\hline Final consumption & 78.89 & 80.84 & 85.13 & 88.91 \\
\hline Share of RES in gross final consumption, $\%$ & 11.0 & 15.1 & 18.9 & 20.4 \\
\hline
\end{tabular}

* the forecast for 2020-2035 does not take into account the energy received from the HPP ** IEA data 
Priorities for the development of the electric power industry will be optimization of the structure of generating capacities, taking into account the peculiarities of attraction to the energy balance of renewable energy and development of power supply networks, which implies the reduction of transformation rates and the approximation of high-voltage networks to the consumer, increasing the flexibility of the system through the implementation of network principles.

The development of thermal generation will be determined by the availability and cost of coal and natural gas reserves, as well as the development of energy technologies for the use of biomass and other fuels. Due to the projected high cost of natural gas conservation, a significant proportion of coal generation is expected to be saved. At the same time, the requirements for limiting the negative impact of energy on the environment will require a large-scale modernization and renewal of thermal power generation capacities, which will lead to a relative stabilization of the total installed capacity of coal TPPs at the existing level.

Of course, increasing energy independence is impossible without modernizing the national energy infrastructure, attracting new modern efficient and energy-saving technologies. Increasing domestic and foreign investment in energy is the most effective solution to this problem. For this purpose it is necessary to work on demonopolization of the energy sector, development of competition, implementation of European norms and market principles of work in the energy sector. A transparent and fair energy market with clear rules of the game is the key to the progressive development of Ukrainian energy.

The development of renewable (or green) energy is not only a popular global energy trend these days; it is also of great global importance. The fossil fuels that underlie energy production in the world today have limited reserves that will sooner or later be depleted. Therefore, not only Ukraine but also all countries that care about their future are tasked with balancing electricity production so that they do not depend solely on temporarily available resources.

For Ukraine, active use of renewable energy sources is especially important, as our country imports part of the traditional fuel and energy resources. Thus, an increase in the share of "green energy" fits into the overall national strategy for diversification of energy sources and will help to strengthen energy independence. 


\section{Innovative model of development of fuel and energy com- plex of Ukraine}

Our research has confirmed the systemic crisis of the fuel and energy complex, the development of which, if ignored, will threaten the entire economic complex of Ukraine and the existence of the state as a whole. As a variant for overcoming this crisis in the environment of scientists, specialists, experts, in recent years, a consolidated opinion was developed about the need for restructuring of the FEC of Ukraine by applying an innovative model of its development.

It should be noted that today the innovative direction of development is the basic strategy for business, where knowledge together with social capital creates competitive advantages of individual countries and regions to a greater extent than their natural resources [5]. Innovation processes are becoming a major source of economic growth, especially in the context of the current paradigm of sustainable development and scarcity of natural resources, including energy [62]. Quality technological and organizational change is the basis of innovation.

Strategic directions of innovation activity are legislatively determined for the FEC of Ukraine modernization of power plants; new and renewable energy sources; the latest resource-saving technologies; protection and rehabilitation of the person and the environment.

Considering the technological level of the fuel and energy complex, the total need for innovative financing (according to experts) annually ranges from 8 to 12 billion UAH. Undertakings will not be able to obtain such financial resources without their own foreign investments.

Therefore, the problem of creating an attractive investment climate in the fuel and energy complex of Ukraine for the activation of innovative processes has become of particular importance.

As noted by the specialists of the National Institute for Strategic Studies, in order to increase the investment attractiveness of the innovative market of FEC of Ukraine, it is necessary to carry out a consistent set of measures, which are summarized in Table 1. 
Table 1

Measures to create an attractive one investment climate in FEC of Ukraine

\begin{tabular}{|c|c|c|}
\hline And the stage is until 2021 & Stage II - by 2025 & Stage III - by 2035 \\
\hline $\begin{array}{l}\text { 1. Formation of a support system } \\
\text { for the implementation of energy } \\
\text { technologies and management } \\
\text { systems (stimulation of the intro- } \\
\text { duction of innovative technolo- } \\
\text { gies), the creation of a system of } \\
\text { scientific and technical centers for } \\
\text { technology development, research } \\
\text { and development of personnel } \\
\text { potential of energy (grants, schol- } \\
\text { arships, financing of study abroad). } \\
\text { 2. Provision of financial support } \\
\text { for basic and applied research. }\end{array}$ & $\begin{array}{l}\text { 1. Ensuring the partic- } \\
\text { ipation of domestic } \\
\text { research institutions in } \\
\text { EU scientific and } \\
\text { technological pro- } \\
\text { grams and bringing } \\
\text { Ukraine closer to the } \\
\text { European scientific } \\
\text { space. }\end{array}$ & $\begin{array}{l}\text { 1.Creation of national } \\
\text { energy companies } \\
\text { (power engineering in } \\
\text { hydropower, energy } \\
\text { production and supply } \\
\text { companies) and sup- } \\
\text { port of their entry into } \\
\text { foreign markets. }\end{array}$ \\
\hline $\begin{array}{l}\text { 3.Approval of the methodology for } \\
\text { estimating the cost of capital that } \\
\text { can be taken into account for the } \\
\text { formation of tariffs for products } \\
\text { and services for different branches } \\
\text { of FEC }\end{array}$ & $\begin{array}{l}\text { 3.Approval of the } \\
\text { methodology for esti- } \\
\text { mating the cost of } \\
\text { capital that can be } \\
\text { taken into account for } \\
\text { the formation of tariffs } \\
\text { for products and ser- } \\
\text { vices for different } \\
\text { branches of the FEC }\end{array}$ & \\
\hline $\begin{array}{l}\text { 4. Formation of a national energy } \\
\text { technology transfer network, state } \\
\text { support for technology transfer } \\
\text { (technology buy-out), localization } \\
\text { of energy technology production. }\end{array}$ & $\begin{array}{l}\text { 3. Formation of sys- } \\
\text { tem of support of ven- } \\
\text { ture activity and trans- } \\
\text { fer of energy technol- } \\
\text { ogies, development of } \\
\text { the Ukrainian engi- } \\
\text { neering companies. }\end{array}$ & $\begin{array}{l}\text { 2. Implementation of } \\
\text { pilot projects for car- } \\
\text { bon capture and stor- } \\
\text { age, recycling of } \\
\text { household waste, etc.. }\end{array}$ \\
\hline $\begin{array}{l}\text { 5. Introduction of new specialties } \\
\text { for the energy sector and new } \\
\text { training programs for training } \\
\text { specialists in educational institu- } \\
\text { tions in order to prepare staff to } \\
\text { work in the energy markets in the } \\
\text { following areas: } \\
\text { - energy economy (energy trading, } \\
\text { day-ahead markets, balancing } \\
\text { markets, ancillary services mar- } \\
\text { kets); } \\
\text { - "energy technologies" (modern } \\
\text { innovative technologies in energy); } \\
\text { - "project analysis in energy" }\end{array}$ & $\begin{array}{l}\text { 4. Ensuring the first } \\
\text { graduation of special- } \\
\text { ists in new educational } \\
\text { programs by higher } \\
\text { education institutions. }\end{array}$ & $\begin{array}{l}\text { 3. Improvement of } \\
\text { training programs for } \\
\text { training specialists in } \\
\text { accordance with the } \\
\text { needs of competition } \\
\text { of Ukrainian compa- } \\
\text { nies in the European } \\
\text { energy markets. }\end{array}$ \\
\hline
\end{tabular}




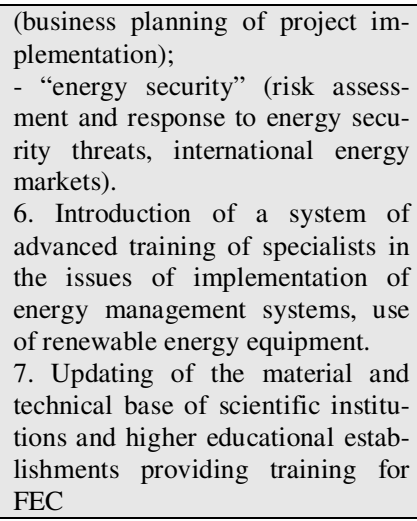

Source: author by [1]

An objective indicator of the effectiveness of innovative activities in the fuel and energy industry, taking into account the requirements of environmental regulation, should be to achieve certain levels of baseline indicators that characterize the efficiency of the fuel and energy and its environmental impact. As an option for possible evaluation, we propose a set of parameters, shown in table 2, formed using data from the National Institute for Strategic Studies.

Achieving these levels of benchmarks requires more than just boosting investment activity. Ultimately, the environmental regulation of FEC (as well as other sectors of the economic complex) requires the construction of a new system of relationships in the chain: central government - regional government (local government) - the entity.

However, the dominant role of central authorities in the implementation of the system of environmental regulation and control of this process has objectively encountered insurmountable difficulties in the current conditions, namely: lack of effective and objective environmental monitoring; poor control over the implementation of state environmental programs and a formal approach to monitoring the implementation of regional environmental programs.

At the same time, regional authorities and local self-government (unlike similar structures in EU Member States) do not consider the environmental issues of their territories as absolutely priority issues, 
focusing mainly on socio-economic issues, the state of housing and communal services, and employment.

The innovative model of the development of the FEC of Ukraine, taking into account the requirements of environmental regulation, requires a change in the system of relations between the authorities, strengthening the competence, activity and capacity of local authorities to solve environmental problems created by the entities in the respective communities, and Euroadaptation of the FEC consistent investment from business entities, as well as EU budget support and financial assistance.

Table 2

Baseline performance indicators the functioning of the FEC and its environmental impact

\begin{tabular}{|c|c|c|c|c|}
\hline Indicators & 2020 & 2025 & 2030 & 2035 \\
\hline $\begin{array}{l}\text { 1.Energy intensity of GDP, } \mathrm{kgc} / \mathrm{S} \\
1 \text { of GDP }\end{array}$ & 0,27 & 0,23 & 0,20 & 0,17 \\
\hline $\begin{array}{l}\text { 2. Fuel costs for TPP for electricity } \\
\text { generated, gp / kWh. }\end{array}$ & 384 & 367 & 353 & 334 \\
\hline $\begin{array}{l}\text { 3. The level of residual resource of } \\
\text { FEC fixed assets, } \% \text {. }\end{array}$ & 30 & 50 & 60 & 80 \\
\hline $\begin{array}{l}\text { 4.Particle shunting power genera- } \\
\text { tion capacity of the fuel power plant } \\
\text { to the total installed capacity, } \% \text {. }\end{array}$ & 12 & 14 & 16 & 18 \\
\hline $\begin{array}{l}\text { 5. Share of losses in the distribution } \\
\text { grids, } \% \text {. }\end{array}$ & 11 & 10 & 9 & 8 \\
\hline $\begin{array}{l}\text { 6. Share of energy trading in the } \\
\text { stock exchange, } \% \text { of domestic con- } \\
\text { sumption, including electricity, coal, } \\
\text { oil, gas and other fuels. }\end{array}$ & 25 & 50 & 60 & 70 \\
\hline $\begin{array}{l}\text { 7. Share of renewable energy } \\
\text { sources in gross final energy con- } \\
\text { sumption, } \% \text {. }\end{array}$ & 11 & 15 & 18 & 20 \\
\hline $\begin{array}{l}\text { 8. Share of local alternative fuels in } \\
\text { local fuel and energy balances, } \% \text { to } \\
\text { total consumption. }\end{array}$ & 10 & 15 & 18 & 20 \\
\hline $\begin{array}{l}\text { 9. Reduction of } \mathrm{CO}_{2} \text { emissions by } \\
\text { end-use, } \% \text {, from } 2010 \text {. }\end{array}$ & $>5$ & $>10$ & $>15$ & $>20$ \\
\hline $\begin{array}{l}\text { 10. Reduction of specific emissions } \\
\text { in } \mathrm{CO}_{2} \text { equivalent at production of } 1 \\
\mathrm{kWh}, \% \text {, from } 2010\end{array}$ & $>5$ & $>10$ & $>15$ & $>20$ \\
\hline
\end{tabular}




\begin{tabular}{|c|c|c|c|c|}
\hline $\begin{array}{c}\text { 11. Reduction of specific emissions } \\
\text { in } \mathrm{CO}_{2} \text { equivalent in production 1 } \\
\mathrm{Gcal} \% \text {, from 2010. }\end{array}$ & $>5$ & $>10$ & $>15$ & $>20$ \\
\hline $\begin{array}{r}\text { 12.Particle capacity in thermal gen- } \\
\text { eration that meets EU environmental } \\
\text { requirements } \mathrm{SO}_{2}, \mathrm{NOx}, \text { ash emis- } \\
\text { sions), } \% .\end{array}$ & 20 & 40 & 80 & 100 \\
\hline
\end{tabular}

Source: author by [1]

Increased investment in environmental programs, effective control and monitoring, application of environmental management at the sectorial, regional levels and directly by economic entities will provide the process of reforming environmental regulatory tools for the Euroadaptation of national energy.

\section{Conclusions}

In the context of Ukraine's energy dependence on Russian supplies and the steady increase in energy prices, the country's burgeoning developing economy suffers significant losses, leading to a decrease in production levels and a slowdown in socio-economic development.

Therefore, the issue of reducing energy dependency through the formation of an effective energy conservation program and the development of alternative energy in Ukraine should be considered as strategically important, which need urgent solution.

Ukraine has significant nuclear and renewable energy potential that can and should be used to stimulate innovative development of the country's economy, energy security and global goals.

Renewable energy plays a critical role in Ukraine's achievement of strategic energy goals, but it also needs to take into account the potential available in the field of energy efficiency, which, in particular, can be used to reduce natural gas consumption.

Given that many power and heat power facilities are outdated and demand is projected to grow, Ukraine's grid needs to build new, more efficient and environmentally friendly facilities.

This requires the formation of an appropriate balance of energy generation capacities: nuclear power, hydropower, solar and wind, biomass energy, other renewable energy sources with the lowest levels of greenhouse gas emissions. 
Taking into account the peculiarities of the use of renewable energy sources, in particular the energy of the sun and wind, which are caused by natural conditions, it is necessary to harmonize and balance the frequency and volume of electricity produced at solar and wind power plants into the unified energy system of Ukraine.

\section{References}

1. Bortniuk T. Yu. Ecological optimization of Ukraine's fuel and energy complex. Lithuania, Klaipeda, 29 January, 2016). Klaipeda University, p. 52-55. (2016)

2. Moshchich S.Z. Environmental regulation of Euroadaptation of national energy. Problems of rational use of socio-economic and natural-resource potential of the region: financial policy and investment: Coll. of sciences. wash. Kiev: SEU; Exactly: NUSPD, 2. P. 162-168.(2015)

3. Moshchich S.Z. Realization of the re-organization of the fuel and energy complex of Ukraine. Problems of rational use of socio-economic and natural resource potential of the region: financial policy and investments of sciences. wash. Kiev: SEU; Exactly: NUPGP, 4. P. 89-97. (2015)

4. Moshchich S.Z. Organizational-managerial methods of environmental regulation and their application at international and national levels [Electronic resource]. Global and national problems of economics: electronic science. kind. / The Nikolaev nat. them. V.O. Sukhomlinsky. Nikolaev, 9. P. 553-558. (2016) Access mode: http://global-national.in.ua/issue-9-2016. - Title from title. screen.

5. S. Moshchich Problematic Issues of Biotechnology Development in Energy of Ukraine. The impact of bioenergy on the spatial development of territories: Proceedings of the International Scientific and Practical Conference (Kyiv, September 14-15, 2018) K., Comprint, P. 266. (2018)

6. Current state of implementation of rational subsoil use in Ukraine. Ignatyuk I., Malanchuk E., Malanchuk L., Moshchych S., Zagorovsky V. Science, Education and Culture in Eurasia and Africa: the 5th International Academic Congress, (France, Paris, 23-25 March 2015). Papers and commentaries. Paris University Press, 4., P. 328-331.(2015)

7. Ecological-economic problems of development of the peat industry in Ukraine. M. Shershun, I. Timoshchuk, S. Moshchych. British Journal of Science and Education and Culture. - London University Press, V.3., 1(7). P. 240-247. (2015). 